\title{
ANALYSIS OF PROSPECTIVE BIOLOGY TEACHER CAPABILITIES IN ACQUIRING THE LEARNING CONCEPTS AND BIOLOGY SCIENCE MATERIALS IN JUNIOR HIGH SCHOOLS
}

\author{
Kurnia Ningsih \\ Biology Education, Tanjungpura University Pontianak \\ E-mail: niauntan@yahoo.com
}

DOI: dx.doi.org/10.26418/jpmipa.v11i1.31027

\begin{abstract}
This study was aimed to analyse the ability of prospective Biology teachers to master the learning concepts and Biology Science materials in Junior High Schools. The used method in this study was a descriptive analysis, involving some prospective teachers (the students who were taking micro-teaching courses (PPL-1) in even semester of 2017/2018 academic year) in the Biology Education Study Programme FKIP Untan, as the research subjects. A total of 30 university students with GPA $\geq 3.00$ were randomly selected. The instrument in this study was an ability assessment of learning concepts and materials of Biology Science in junior high schools. The data analysis was done in descriptively qualitative and quantitative methods; including data collection, data reduction, data presentation, data analysis using means and percentages, and conclusions eventually. The results showed that the prospective Biology teachers in mastering the concept of learning obtained an average value of 76.89 with $A, B$, and $C$ grades respectively, $46.67 \%$, $40.00 \%$, and $13.33 \%$. For mastering the biology science concept, it was obtained an average value of 75.73 with grade $A, B$, and $C$ respectively, $33.33 \%, 46.67 \%$, and $20.00 \%$. It was certainly concluded that the ability of prospective biology teachers in mastering the concepts of learning and the materials of Biology Science was classified into the good category.
\end{abstract}

Keywords: learning, concepts, biology science materials

Future teachers are encouragingly required to master the pedagogic knowledges, one of them is the learning concept. The learning concept in education is interactively implemented in inspirational, pleasurable and challengeable ways in order to motivate students to actively taking part; it is also providing an adequately necessary space for the initiative, creativity and independence of students according to their talents, interests, physical and psychological development (Permendikbud, 2016). The fundamental

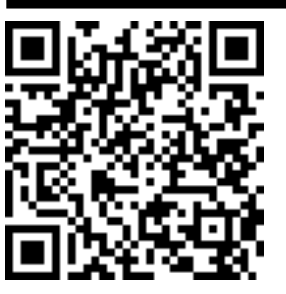

$\begin{array}{ll}\text { Received } & : 22 / 01 / 2019 \\ \text { Revised } & : 13 / 12 / 2019 \\ \text { Accepted } & : 18 / 12 / 2019\end{array}$


Vol. 11, No. 1 (2020) h. 22-33

concept of the learning process is a positive postulation reflecting students as the subjects that are highly capable to actively discover, process, construct and use knowledge. Hence, prospective teachers are obligatory to master the learning concept theoretically and practically.

Apart of understanding the learning concept, prospective teachers are necessarily recommended to comprehend the learning materials based on their teaching subjects. This is accordingly identical to the statement of Kunandar (2011); Zulkifli \& Royes (2017) regarding the teacher competencies; every teacher is strongly advised to deliver competently their teaching lessons to students. The prospective Biology teachers are advisable to at least understand the minimum standard of Biology modules, either for the competency levels in junior high schools (SMP) or senior high schools (SMA). The comprehension of materials for both the teachers and the future educators is closely related to the learning outcome of students. If a potential teacher adequately masters one of their teaching modules, this will benefit for both parties in easily delivering and absorbing the lessons. In transferring knowledge, it may certainly associate to some methods that are being used. The accuracy in selection of methods, strategies, approaches and learning models will influence the studying results of students. This is agreed by Slavin (2011), stating that teachers can facilitate students in constructing their own thoughts, which results to meaningful and relevant information for students in receiving knowledges. In this case, if the methods used by teachers are precise in transferring knowledge, the result may lead to the meaningful learning process.
In National Curriculum 2013, the learning process is advisable to use scientific approaching. To strength the scientific approaching, integrated thematic (intrasubject) and thematic (intersubject) are necessarily implemented to have the discoveryinquiry based learning method. In order to encourage students to generate contextual works individually and group basis, it is advisable to use the learning approaches that generate project-based learning systems (Permendikbud, 2016; Dewi et al., 2017).

Natural Science is the branch of knowledge that learns about the natural phenomenon, including living and unliving organisms. The Science subject is scientifically discovered and developed across the series of researches by scientists in searching for knowledgeable answers of questions of "what?", "why?", and "how?" about the symptoms of natural phenomenon and their application in technology and daily life (Rahayu, 2012). The learning of Natural Science emphasises on the implementation of direct learning experience to develop competencies in order to enable students to explore and understand scientifically the natural surroundings. Thus, it is necessarily acquired to comprehend the concept of Natural Science for teachers and future educators who will teach the concept.

With the course of micro-teaching (PPL-1), prospective teachers and university students who take the course will get trained in applying for their abilities in the learning process at a small class. Otsupius (2014); Rahmawati \& Suriani (2016) demonstrated that the micro-teaching course is a training technique for potential teachers in learning the studying process. This learning concept uses a factual situation 
in order to develop teaching skills and to help teachers attain more in depthknowledge about the art of teaching by the reduction of some teaching complexities that is significantly related to the total students in a class, content scope and time framing.

Besides of mastering the teaching subjects, future teachers are mandatory to learn the basic concept of learnings, regarding the models, strategies and approaching as well as the used learning methods. Importantly, prospective teachers are also compulsory to master the assessment of the learning process of National Curriculum 2013. For those who take the micro-teaching course (PPL-1), it is expectable that they have mastered the basic concepts of learnings and the comprehension of materials that will be taught in classes.

Prospective teachers advisably must know about what must be carried out during the learning process as to necessarily have an optimal comprehension of the use of varied methods that is creative and innovative in order to attract student attentions (Larlen, 2013; Adnan, 2017; Supriadi, 2017). According to Sihes (2014), learning is based on the stages of its complexity; beginning from the easiest learning styles to the complex ones, so that students are easily understandable to them. Learning is the process of facilitating students as to a good teaching environment, thus it is highly required to understand the methods and the learning models (Hanafi, 2014; Salmi, 2019; Andriani, 2015). The knowledge about the varied learning methods will be used by the prospective teachers to teach a certain material on their subjects, such as Natural Science (IPA). This is eventually expected that the future teachers can develop their potencies in selecting a precise method in the learning process. This learning concept is referred to the concepts that will be used by both teachers and potential educators in educating students through the learning methods, learning strategies, learning approaches and learning models that are suitable for their teaching modules.

The mastering of materials that will be taught in class is advisedly possessed by teachers and future educators accordingly to their subjects. Nevertheless, there are some university students (prospective teachers) that have not mastered their teaching materials while doing the training of microteaching course (PPL-1). Based on the results of the observation produced on April $11^{\text {th }}, 2018$ on a few prospective teachers (university pupils taking the micro-teaching course (PPL-1) that is considered from RPP assessment and peer-teaching), it was obtained that approximately $25 \%$ of 8 students did not master their teaching courses. Similarly, in the mastering of learning concept, there were some students still irrelevant in determining models and methods of the learning materials. Of eight students, there was about $37.5 \%$ of who were not accurate in selecting the learning methods and models over their teaching modules.

Other studies correspondingly agreed to the above explanation. It was revealed that the results, regarding to the future teacher abilities in compiling scientific-based RPP, provided an average value of 78,97 with a good category in the first RPP arrangement; an average value of 84,52 with a very good category in the second RPP arrangement; and an average value of 96,00 with a very good category in the third RPP arrangement (Chusni et al., 2017). Other results from Machin (2014) stated the 
Vol. 11, No. 1 (2020) h. 22-33

application of scientific approaches positively influenced the results of cognitive, affective, and psychometric learnings of students; and successfully achieved to the classical finishing that has been established before. Another different result performed by Indriati (2012) also demonstrated that the application of science-edutainment learnings with animation is potential to increase the learning outcomes of students on the concept of light. Sadiqin et al., (2017) similarly investigated the comprehension of Natural Science concepts on junior high school students, through the learning method of problemsolving style, on the topic of object alterations surrounding us, which was obtained the means of student concept understanding at 52,28, before studying, with the poor category; while the average outcome after studying was 77,40 at the good category. The student thinking ability in observing an object, abstract, discrimination and problem rule setting is still sorted at the very good category.

Therefore, from what has been elaborated previously, it is necessarily required to conduct a further study of an ability analysis of future teachers, in mastering the learning concepts and Biology Science materials in junior high schools, on university students who are in the study programme of Biology Education in academic year 2017/2018.

\section{METHOD}

The used method in this study was a descriptive analysis. This analysis was aimed to provide a portrait of the existing variables of field phenomenon in the research sites (Sugiyono, 2015). This study drew about the mastering skills of the learning concepts and Biology Science materials on the prospective Biology teachers for junior high schools.
The implemented activities in this study were: (1) determination of a randomly research subject, (2) providing a research instrument to the research subjects, (3) collecting the research data, (4) analysing the results of study, (5) concluding the research result, and (6) making the report of study.

The subjects involving in this research were the future teachers, currently taking the micro-teaching course (PPL-1) at even semester in $2017 / 2018$ on the study programme of Biology Education, with a total of 30 people who were randomly selected. Another detail of the selected students in this study was each of 10 people placed at class $\mathrm{A}$ and class $\mathrm{B}$, and other 10 people located at class PAPK, with GPA of $\geq 3,00$.

The procedure in this study was consisting of three steps. First, the preparation step; (1) in this step, the researchers conducted an observation to collect the initial data of learning concepts and Biology Science materials on the prospective teachers, including providing the research instruments by making some drafts and questions, and finally testing the requirements of research instruments. Second, the implementation step; (2) all the instruments that have been complied to the procedure of requirement test were given to the research subjects by providing an ability test of the concepts of learnings and Biology Science, then data collection was performed to reduce some unusable data to further analyse in order to take a conclusion. Third, (3) the reporting step.

The research instrument used as a data collection tool was the test question of the basic learning concepts and Biology Science materials. The questions of the basic learning concepts comprise 
Vol. 11, No. 1 (2020) h. 22-33

of the method, strategy, approach, learning model, assessment, and its application in the Biology Science learnings in junior high schools. The Biology Science materials consist of several essential chapters such as food web, classification of living organisms, genetics, symbiosis and ecosystem, meristem tissues and other plant tissues, plant motions, photosynthesis, digestion system, circulatory system, sensory system, hormonal system, environmental pollution and biotechnology. The total of questions given to the subjects for the learning concepts were 15 , while the total of 25 questions were assigned for the Biology Science materials, both in multiple choice based.

The questions of the ability assessment for the future teachers, about the learning concepts and Biology Science materials in junior high schools, were considered as an indicator to measure their abilities. Besides, there were some answer sheets used to determine their GPA and their class type as the prospective Biology teachers.

Every tool of data collection must have a validation and reliability in order to have a good tool of data collection (Djaali \& Muljono, 2008). The questions given to the prospective teachers were adapted from the questions of the competency test of Natural Science for teachers in junior high schools. The selected questions were initially assessed of their validation and reliability. The assessment of the instrument validation by using the content validity was done by an educational expert. While, the assessment of the instrument reliability was done by using the alpha-cronbach analysis (Azwar, 2013). The results of the content validity assessment on the questions of the learning concepts and Biology Science materials were claimed valid by the experts, and the results measured for the reliability of the learning concepts and Biology Science materials were presented at 0,59 and 0,61 , respectively. Considering these two values, the instruments used in this study have fulfilled the valid and reliable requirements.

The data analysis techniques used in this study were quantitative and qualitative descriptive analysis (Creswell $\&$ Clark, 2007). The steps of data analysis using the qualitative and quantitative methods encompass of data collection, data reduction, data display and analysis using means and percentage, and conclusion. The type of data collected in this study was quantitative and qualitative type. The quantitative data type was analysed by scores, grades, averages and percentages, while qualitative type was by category classification.

To determine average, percentage and category classification, the capability of the potential Biology teachers in mastering the learning and Biology Science concepts was referred to:

1. Scoring; where 1 is for true and 0 is for wrong

2. Grading

3. Calculating means

4. Calculating percentage

5. Determining category

\begin{tabular}{cc}
\hline Grade Range & Category \\
\hline $80 \leq \mathrm{A} \leq 100$ & Very Good \\
$70 \leq \mathrm{B}<80$ & Good \\
$60 \leq \mathrm{C}<70$ & Adequate \\
$50 \leq \mathrm{D}<60$ & Less \\
\hline
\end{tabular}

\section{RESULTS AND DISCUSSION}

The data of this finding provided the results of the ability test of the future teachers on the learning concepts and Biology Science materials. This study 
involved the total of 30 participants. The data was obtained from all collections of the test results, then was reduced according to the examined concepts, which were the basic learning and Biology Science. Furthermore, to assess the ability of the prospective teachers in mastering the both concepts, it could be referred to the obtained values of average and percentage. The achieved average values were initially performed by scoring, then converting them to the grade system. The ability of the prospective Biology teachers in mastering the learning and Biology Science concepts was shown in the form of grade displaying in Table 1.

Table 1. The Ability of the Prospective Biology Teachers in Mastering the Learning and Biology Science Concepts in Junior High Schools

\begin{tabular}{lcc}
\hline Grade (Category) & Basic Concept of Learning & Biology Scince Materials \\
\hline Average & 76,89 & 75,73 \\
\hline A (Very Good) & $46,67 \%$ & $33,33 \%$ \\
\hline B (Good) & $40,00 \%$ & $46,67 \%$ \\
\hline C (Adequate) & $13,33 \%$ & $20,00 \%$ \\
\hline
\end{tabular}

In this current study, the total of those participants who were currently taking the micro-teaching course were 30 people, who have been provided with the test questions of the learning and Biology Science concepts that have been divided into 15 and 25 questions for each concept. After that, the scoring was performed. The obtained scores from those participants were then converted into the grade system. Based on the results, it was obtained that the average values of mastering both the basic learning concepts and the Biology Science essential concepts were at 76,89 and 75,73 , respectively. These findings showed that the ability of the future Biology teachers was at the good category. This was obtained from the measured values of each question of the learning and Biology Science concepts. The percentage of the proficiency in the learning concepts on the prospective Biology teachers was displayed in Table 2.

Table 2. Proficiency Percentage of Learning Concepts on the Prospective Biology Teachers

\begin{tabular}{llccc}
\hline No. & Learning Concept & $\begin{array}{c}\text { Question } \\
\text { Number }\end{array}$ & $\begin{array}{c}\text { Proficiency } \\
(\boldsymbol{\%})\end{array}$ & $\begin{array}{c}\text { Average of } \\
\text { Each Concept } \\
(\%)\end{array}$ \\
\hline 1 & Determination of BC and & 4 & 70,00 & 73,34 \\
\hline & Learning Objectives & 10 & 76,67 & \\
\hline 2 & Determination of Learning & 1 & 93,33 & 86,67 \\
& Methods & 2 & 86,67 & \\
& 11 & 80,00 & \\
\hline
\end{tabular}


Vol. 11, No. 1 (2020) h. 22-33

\begin{tabular}{llccc}
\hline No. & Learning Concept & $\begin{array}{c}\text { Question } \\
\text { Number }\end{array}$ & $\begin{array}{c}\text { Proficiency } \\
(\boldsymbol{\%})\end{array}$ & $\begin{array}{c}\text { Average of } \\
\text { Each Concept } \\
(\%)\end{array}$ \\
\hline 3 & Identification of Learning & 3 & 83,33 & \\
& Models & 7 & 66,67 & 76,67 \\
& & 8 & 80,00 & \\
\hline 4 & Analysis of Assessment & 5 & 86,67 & \\
& Technique in Learning & 6 & 73,33 & \\
& & 9 & 70,00 & \\
& & 12 & 86,67 & \\
& & 13 & 73,33 & \\
& & 14 & 63,33 & \\
& & 15 & 63,33 & \\
\hline
\end{tabular}

Table 2 showed that the learning concept, especially in determining the Basic Competency (KD) and the learning objectives, of the potential Biology teachers was at 73,34 with a good category; it was obtained from the question number (4) regarding the providing of the Basic Competency, where the future teachers were requested to determine the learning objectives and the question number (10) regarding the request of selecting some relevant learning activities. This is correspondingly suitable with the results performed by Chusni, et al. (2017), that prospective Physics teachers in constructing the learning objectives were at the good category.

The mastery of determining the learning objectives by the potential Biology tutors, preceding with the initial case, was obtained about $86,67 \%$ at the very good category; this was obtained from questions number (1), (2) and (11). For instance, question number (1), while teaching the chapter of digestion system, teachers generally use the display of torso as the learning tool. By involving students in the class, teachers will appoint some organs of the torso that get involved with the digestion system and will explain the mechanisms of digestion system during the eating process. The learning method selected by them was a demonstration method; this question was answered true by the university students (prospective teachers) taking the microteaching course, with a percentage of $93,33 \%$. In this case, the proficiency of the learning concept, especially the learning method, has been possessed by the future Biology teachers. Another study performed by Chusni et al., (2017) also agreed that, in the determination of learning methods, the future teachers had no experience of difficulty. This was obviously shown on the results of an assessment on RPP $1(80,74)$, RPP 2 $(80,74)$ and RPP $3(97,04)$. According to the construction of the RPP 1 to 3 , it was shown the expansion of capability in determining the learning methods. Besides, Woolfolk (2009); Sulthon (2016) stated that learning is a process where an experience may cause alterations in knowledge and steady behaviours.

As for the proficiency in identification of the use of learning models in teaching Biology Science, the 
prospective Biology teachers obtained an average value of $76,67 \%$ at the good category. This achievement was obtained from number (3), (7) and (8) explaining about the learning models through discovery-learning methods, practical learnings and problem-solving based. The comprehension of Biology Science concepts and the thinking ability have widely developed through the problemsolving-based learning methods. This development has occurred since students are capable enough of selecting the learning process and connecting the declarative and procedural knowledge while finishing the learning problems (Sadiqin et al., 2017).

The result of the prospective Biology teachers in analysing the techniques of learning assessment was categorised in the good category. This was shown based on their abilities in accomplishing those questions related to the assessments, which were from number (5), (6), (9), (12), (13), (14) and (15). On the assessment of the working capability (numbered 14 and 15), the achievement was classified into the adequate category. This finding also has been supported by another study by Astuti et al., (2015) stating that there was merely a rise of the means score on the working performance of the prospective Biology teachers in arranging drafts, either in experimental or control groups. The improvement of the average scores derived from the experimental groups was 1,86 to 3,49 ; while the improvement for the control groups was 2,23 to 3,42 . Moreover, the proficiency in the analysis concepts of assessment types in the Biology Science learning, numbered (5) and (12), was at the very good category.

Biology Science concept is a concept which is mandatory for each future Biology teacher in both teaching theoretically and practically in junior high schools. The Natural Science concepts are factual, conceptual, procedural and metacognitive (Anderson \& Kratwohl, 2010). Teachers or prospective teachers play a role of providing materials in order to offer contextual and meaningful situations and conditions, so that students are not only memorising but also mastering the concepts and applying in the daily life. As for the mastery of Biology Science materials in junior high schools, the prospective teachers were given about 25 questions and the results were shown on the Table 3.

Table 3. Mastery of Biology Science Concepts on the Prospective Biology Teachers

\begin{tabular}{|c|c|c|c|c|}
\hline No. & $\begin{array}{l}\text { Biology Science Concepts } \\
\text { In Junior High School }\end{array}$ & $\begin{array}{l}\text { Question } \\
\text { Number }\end{array}$ & $\begin{array}{c}\text { Proficiency } \\
(\%)\end{array}$ & $\begin{array}{l}\text { Average of Each } \\
\text { Concept }(\%)\end{array}$ \\
\hline \multirow{2}{*}{1} & \multirow{2}{*}{ Symbiosis } & 1 & 93,33 & \multirow{2}{*}{86,67} \\
\hline & & 5 & 80,00 & \\
\hline \multirow{3}{*}{2} & & 2 & 83,33 & \multirow{3}{*}{81,11} \\
\hline & Classincation or Living & 3 & 90 & \\
\hline & Urganısms & 25 & 70 & \\
\hline \multirow{2}{*}{3} & \multirow{2}{*}{ Ecosystem } & 10 & 73,33 & \multirow{2}{*}{71,67} \\
\hline & & 12 & 70 & \\
\hline 4 & Genetics & 4 & 80 & 80 \\
\hline
\end{tabular}


Jurnal Pendidikan Matematika dan IPA

Vol. 11, No. 1 (2020) h. 22-33

\begin{tabular}{|c|c|c|c|c|}
\hline No. & $\begin{array}{l}\text { Biology Science Concepts } \\
\text { In Junior High School }\end{array}$ & $\begin{array}{l}\text { Question } \\
\text { Number }\end{array}$ & $\begin{array}{c}\text { Proficiency } \\
(\%)\end{array}$ & $\begin{array}{c}\text { Average of Each } \\
\text { Concept }(\%)\end{array}$ \\
\hline \multirow{4}{*}{5} & \multirow{4}{*}{ Plants Tissues } & 6 & 76,67 & \multirow{4}{*}{76,67} \\
\hline & & 7 & 80 & \\
\hline & & 11 & 83,33 & \\
\hline & & 24 & 66,67 & \\
\hline 6 & Plants Motions & 8 & 73,33 & 73,33 \\
\hline \multirow{2}{*}{7} & \multirow{2}{*}{ Photosynthesis } & 9 & 73,33 & \multirow{2}{*}{71,67} \\
\hline & & 13 & 70,00 & \\
\hline \multirow{7}{*}{8} & \multirow{7}{*}{ Systems of Living Organisms } & 14 & 63,33 & \multirow{7}{*}{68,57} \\
\hline & & 15 & 66,67 & \\
\hline & & 16 & 66,67 & \\
\hline & & 18 & 80,00 & \\
\hline & & 19 & 63,33 & \\
\hline & & 22 & 60,00 & \\
\hline & & 23 & 80,00 & \\
\hline \multirow{2}{*}{9} & \multirow{2}{*}{ Environmental Conservation } & 20 & 80,00 & \multirow{2}{*}{80,00} \\
\hline & & 21 & 80,00 & \\
\hline \multirow[t]{2}{*}{10} & Biotechnology & 17 & 90,00 & 90,00 \\
\hline & Average & & 75,7328 & \\
\hline
\end{tabular}

Based on the results of the proficiency of the Biology Science concepts, the symbiosis concept was achieved at $86,67 \%$ with the very good category; this was revealed on the questions number (1) and (5). As for the concept of the classification of living organisms, the proficiency of the prospective Biology teachers was nearly $81,11 \%$ with the very good category, shown in the questions number (2), (3) and (25). Similarly, the proficiency of the potential Biology educators in the concept of genetics was represented in the question number (4), the concept of environmental conservation was number (20) and (21), and biotechnology concept was number (17), that were obtained at $80 \%, 80 \%$ and $90 \%$, respectively, with the very good categories.

The mastery of the Biology Science concepts on the future Biology Science teachers was classified into the good category, involving the concepts of ecosystem, plant tissues, plant motions and photosynthesis. The results of these findings demonstrated that the concept of ecosystem was shown on number (10) and (12) at the percentage of $71,67 \%$; the concept of plant tissues was on number (6), (7), (11) and (24) at 76,67\%; the concept of plant motions was on number (8) at $73,33 \%$; and the concept of photosynthesis was by number (9) and (13) at 71,67\%, with the good categories; all questions were the reasoning-based type. This is agreed by the results of Sadiqin, et al. (2017) stating that the student thinking ability in observing objects, abstracts and discrimination, and rule setting was classified in the very good category.

Of 25 questions being tested, there were several questions number (14), (15), (16), (18), (19), (22) and (23) representing the concepts of system in living organisms that are consisted of digestion system, sensory system, regulation system and hormonal system. All these concepts were not fully 
mastered by the prospective Biology teachers shown by the percentage obtained at approximately $68,57 \%$, with the adequate category. This was caused by the broad spectrum of the teaching materials (questions based) and the large number of questions asked by those participants compared to the other concepts.

\section{CONCLUSION AND SUGGESTION}

The results on this study revealed that the prospective Biology teachers in mastering the learning concepts were able to achieve the average percentage of about $76,89 \%$ with the following grade of $\mathrm{A}, \mathrm{B}$ and $\mathrm{C}$ at $46,67 \%, 40,00 \%$ and $13,33 \%$, respectively. For the proficiency of essential-material concepts of Biology Science, it was obtained the grades of A, $\mathrm{B}$ and $\mathrm{C}$ with the following percentage of $33,33 \%, 46,67 \%$ and $30,00 \%$. Therefore, in conclusion, the ability of the prospective Biology teachers in mastering the learning and Biology Science concepts in the National Curriculum 13 was at the good category.

It is strongly advised that university lecturers at the micro-teaching (PPL-1) course should constantly pay and emphasise more details and attentions on the proficiency of the learning concepts and teaching materials on their students by examining their grades of prerequisite courses.

\section{REFERENCES}

Adnan, M. (2017). Urgensi Penerapan Metode Paikem Bagi Guru Dalam Meningkatkan Mutu Pembelajaran Pendidikan Agama Islam. Jurnal Studi Keislaman, 3(1): 133-150. Online (https://media.neliti.com/media/pub lications/268455-urgensi- penerapan-metode-paikem-bagigur-96fbef83.pdf).

Anderson, L W., \& Krathwohl, D R. (2010). Kerangka Landasan Pembelajaran, Pengajaran, dan Asesmen, terjemahan Agung Prihantoro. Yogyakarta: Pustaka Pelajar.

Andriani., Mestawaty, AS. A., dan Paudi, R. I. (2015). Penerapan Model Pembelajaran Berbasis Masalah Dalam Meningkatkan Hasil Belajar Siswa Tentang Pengaruh Gaya Terhadap Gerak Benda di Kelas IV SDN 1 Ogowele. Jurnal Kreatif Tadulako Online, 5(5): 79-92. Online (https://media.neliti.com/media/pub lications/113041-ID-penerapanmodel-pembelajaran-berbasisma.pdf).

Astuti, Y., Wulan, A. R., \& Priyandoko, D. (2015). Pengembangan Kemampuan Mahasiswa Calon Guru Biologi dalam Penyusunan Tugas (Task) Kinerja melalui Perkuliahan Evaluasi Proses dan Hasil Belajar. Proseding Seminar Nasional Pendidikan Biologi. Malang: 175-183.

Azwar, S. (2013). Reliabilitas dan Validitas. Yogyakarta: Pustaka Pelajar.

Chusni, M. M., Setya, W., Agustina, R.D., \& Malik A. (2017). Peningkatan Kemampuan Menyususn Rencana Pelaksanaan Pembelajaran (RPP) berbasis Saintifik bagi Calon Guru Fisika. Scientiae Educatia: Jurnal Pendidikan Sains, Vol 6, No. 2, 125 - 
Vol. 11, No. 1 (2020) h. 22-33

143. Online (http://dx.doi.org/ 10.24235/ sc.educatia.v6i2.1952, akses 27 Oktober 2018).

Creswell, J. W., \& Clark, V. L. (2007). Designing and conducting mixed method research. London: Sage Publications.

Dewi, B., Khoiri, N., dan Kaltsum, U. (2017). Peningkatan Kemampuan Pemecahan Masalah Siswa Melalui Penerapan Model Project Based Learning. Jurnal Penelitian Pembelajaran Fisika, 8(1): 8-13. Online

(http://journal.upgris.ac.id/index.ph p/JP2F/article/view/1331).

Djaali \& Muljono, P. (2008). Pengukuran dalam Bidang Pendidikan. Jakarta: Grasindo.

Hanafi, M. S. (2014). Konsep Belajar dan Pembelajaran. Lentera Pendidikan, Vol 17, No 1, 66-70.

Indriati D. (2012). Meningkatkan Hasil Belajar IPA Konsep Cahaya melalui Pembelajaran Science-Edutainment berbantuan Media Animasi. Jurnal Pendidikan IPA Indonesia. JPII, Vol 1 (2): 192-197. Online (http:// journal.unnes.ac.id/ index.php/jpii, akses 27 Oktober 2018).

Kunandar. (2011). Guru Profesional Implementasi KTSP dan Sukses dalam Sertifikasi Guru. Jakarta: Rajagrafindo Persada.

Larlen. (2013). Persiapan guru bagi proses belajar mengajar. Pena, Vol 3, No. 1, 81-91.
Machin, A. (2014). Implementasi Pendekatan Saintifik, Penanaman Karakter dan Konservasi pada Pembelajaran Materi Pertumbuhan. Jurnal Pendidikan IPA Indonesia, Vol 3, No. 1, 28-35. Online (http: //journal.unnes.ac.id/nju/index.php/ jpii, akses 20 April 2018).

Otsupius, I. (2014). Micro-teaching: a technique for effective teaching. An International Multidisciplinary Journal, Vol 8, No. 4, 183-197. DOI: 10.4314/afrrev.v8i4.15.

Rahayu P, Mulyani S, \& Miswadi S. S. (2012). Pengembangan Pembelajaran IPA Terpadu dengan Menggunakan Model Pembelajaran Problem Base melalui Lesson Study. Jurnal Pendidikan IPA Indonesia. JPII, Vol 1 (1): 63-70. Online (http:// journal.unnes.ac.id/ index.php/jpii, akses 27 Oktober 2018).

Rahmawati, L., \& Suriani. (2016). Persepsi Mahasiswa Tentang Efektivitas Mata Kuliah Microteaching Terhadap Pelaksanaan Program Pengalaman Lapangan (PPL) Mahasiswa S1 Program Studi Pendidikan Biologi FMIPA Universitas Negeri Medan. Jurnal Pelita Pendidikan, 4(3): 5863. Online (jurnal.unimed.ac.id> index.php).

Sadiqin, I. K, Santoso, U. T, \& Sholaluddin, A. (2017). Pemahaman Konsep IPA Siswa SMP melalui Pembelajaran Problem Solving pada Topik Perubahan Benda-benda di Sekitar Kita. Jurnal Inovasi Pendidikan IPA, Vol 3, No. 1, 52-62. Online (http: // journal.uny. ac.id/index.php/jipi, 4 Mei 2018). 
Salmi. (2019). Penerapan Model Pembelajaran Discovery Learning Dalam Meningkatkan Hasil Belajar Ekonomi Peserta Didik Kelas XII IPS.2 SMA Negeri 13 Palembang. Jurnal Profit, 6(1): 1-16. Online (https://ejournal.unsri.ac.id/index.p hp/jp/article/view/7865).

Sihes, A. J. (2014). Konsep Pembelajaran. Artikel. Online (https://widuri.raharja.Info/index.ph p/Konsep_Pembelajaran, akses 29 April 2018).

Slavin, R E. (2011). Psikologi Pendidikan: Teori dan Praktek, terjemahan Marianto Samosir. Jakarta: Indeks.

Sugiyono. (2015). Metode Penelitian Pendidikan Pendekatan Kuantitatif, Kualitatif, dan $R \& D$. Bandung: Alfabeta.

Sulthon. (2016). Pembelajaran IPA yang Efektif dan Menyenangkan Bagi Siswa Madrasah Ibtidaiyah (MI). Elementary, 4(1): 38-54. Online (http://journal.stainkudus.ac.id/inde x.php/elementary/article/view/1969 ) .

Supriadi, D. (2017). Implementasi Manajemen Inovasi dan Kreatifitas Guru dalam Meningkatkan Mutu Pembelajaran. Indonesian Journal of Education Management and Administration Review, 1(2): 125132. Online (https://jurnal.unigal.ac.id).

Woolfolk, A. (2009). Educational psychology: Active learning, terjemahan Helly P Soetjipto dan Sri M Soetjipto. Psikologi Pendidikan: Pembelajaran Aktif. Yogyakarta: Pustaka Pelajar.

Zulkifli., \& Royes, N. (2017). Profesionalisme Guru Dalam Mengembangkan Materi Ajar Bahasa Arab di MIN 1 Palembang. JIP: Jurnal Ilmiah PGM, 3(2): 120132.

Online (http://jurnal.radenfatah.ac.id/index. php/jip/article/view/1646/1329). 